\title{
PENGARUH KONVERGENSI, KOMPLEKSITAS AKUNTANSI, DAN PROBABILITAS KEBANGKRUTAN TERHADAP TIMELINESS DAN MANAJEMEN LABA
}

\author{
Asri Adika Widyawati \\ Fakultas Ekonomi Universitas Indonesia, Program Studi Akuntansi \\ Viska Anggraita \\ Fakultas Ekonomi Universitas Indonesia, Program Studi Akuntansi \\ e-mail: Viskaviska257@yahoo.co.id
}

\begin{abstract}
This research aims to examine the effects of IFRS convergence, accounting complexity, and bankruptcy probability on timeliness and earnings management. This study is an empirical research of non-financial companies listed in the Indonesia Stock Exchange in the period of 2010-2011. Using multiple regression random effects, this study found that the convergence of IFRS which was effective in 2011, accounting complexity and bankruptcy probability extended audit delay and submission of financial statements. This study also found that the convergence of IFRS in 2011 and bankruptcy reduced the level of earnings management of the company. Accounting complexity, on the other hand, did not affect the level of earnings management.
\end{abstract}

Keywords: accounting complexity, bankruptcy prediction, audit delay, timeliness, earning management.

\begin{abstract}
Abstrak
Penelitian ini bertujuan untuk menguji pengaruh konvergensi IFRS, kompleksitas akuntansi dan probabilitas kebangkrutan terhadap timeliness dan manajemen laba, Peneltian ini adalah penelitian empiris yang menguji perusahaan non-keuangan yang terdaftar di Bursa Efek Indonesia antara tahun 2010 dan 2011. Dengan menggunakan regresi berganda random effect, penelitian ini menemukan bahwa konvergensi IFRS yang efektif mulai tahun 2011, kompleksitas akuntansi dan probabilitas kebangkrutan memperlama penundaan audit dan pengumpulan laporan keuangan. Penelitian ini juga menemukan bahwa konvergensi IFRS pada tahun 2011 dan kebangkrutan mengurangi tingkat manajemen laba perusahaan. Akan tetapi, kompleksitas akuntansi tidak mempengaruhi tingkat manajemen laba.
\end{abstract}

Kata kunci: kompleksitas akuntansi, prediksi kebangkrutan, penundaan audit, timeliness, dan manajemen laba.

\section{PENDAHULUAN}

Beberapa tahun terakhir ini, isu globalisasi telah menjadi sebuah fenomena yang tidak dapat dihindarkan dalam dunia bisnis. Sebagai respon atas meningkatnya dampak globalisasi yang semakin kuat, para stakeholder dalam pasar internasional pun berupaya untuk mempermudah dan menyeragamkan bahasa bertransaksi dan berinvestasi (bahasa pelaporan keuangan dan standar keuangan) secara global. Standar pelaporan keuangan dan stan- dar akuntansi global haruslah standar yang dapat diterima dan dipahami masyarakat global sehingga diperlukanlah standar yang sama di seluruh dunia.

IFRS (International Financial Reporting Standards) yang dirumuskan oleh IASB (International Accounting Standard Board) merupakan standar pelaporan keuangan yang diperkirakan dapat menjadi jawaban atas permasalahan tersebut. Di seluruh dunia, IFRS telah diadopsi oleh banyak negara termasuk 
negara Uni Eropa, Afrika, Asia, Amerika Latin, dan Australia. Sejak tahun 2008, diperkirakan sekitar delapan puluh negara mengharuskan perusahaan yang telah terdaftar dalam bursa efeknya menerapkan IFRS dalam mempersiapkan dan menyajikan laporan keuangannya. Indonesia pun secara bertahap merupakan salah satu negara yang sedang mengadopsi IFRS. Pengadopsian IFRS di Indonesia telah menjadi perhatian utama dalam persiapan laporan keuangan bagi manajer maupun auditor. Pengadopsian IFRS dipercaya dapat memberikan peningkatan kualitas pelaporan keuangan dengan meningkatnya komparabilitas dan transparansi bagi para pengguna. Pada tahun 2011, proses konvergensi IFRS semakin mendekati tahap pengimplementasian penuh untuk tahun 2012 . Hal tersebut ditandai dengan efektifnya 16 PSAK yang telah konvergen dengan IFRS.

Globalisasi juga membuka kesempatan perkembangan bisnis yang begitu pesat sehingga mendorong pemilik atau manajemen perusahaan untuk mengembangkan usahanya dengan strategi bisnis baik jangka panjang maupun jangka pendek. Salah satu caranya adalah dengan penggabungan beberapa usaha yang akhirnya mempengaruhi jumlah anak perusahaan yang dimiliki. Bentuk penggabungan usaha yang sering dilakukan adalah merger dan akusisi dimana strategi ini dipandang sebagai salah satu cara untuk mencapai beberapa tujuan yang lebih bersifat ekonomis dan jangka panjang. Perusahaan yang memilih melakukan penggabungan usaha, maka perushaan memilih struktur organisasi yang lebih kompleks. Struktur organisasi yang lebih kompleks tersebut turut mempengaruhi proses pelaporan keuangan akuntansi yang menjadi lebih kompleks dari sebelumnya. Laporan keuangan perusahaan induk perlu dikonsolidasi karena konsolidasi tersebut akan merefleksikan substansi ekonomi dari perusahaan dibawah kepentingan pengendali yang sama. Hasilnya, perbedaan treatment akuntansi antara entitas anak akan berkontribusi ke manajemen pendapatan, biaya, serta transaksi.

Di sisi lain, globalisasi juga dapat meberikan tantangan bagi perusahaan dan organisasi dalam dunia bisnis untuk berusaha menjadi yang terbaik dengan menerapkan proses bisnis yang lebih efektif dan efesien. Keadaan tersebut membuat persaingan bisnis global dari tahun ke tahun semakin besar dan perusahaan yang berupaya memasuki bisnis global semakin banyak. Dengan demikian, perusahaan dalam jangka panjangnya bertujuan untuk mempertahankan kelangsungan hidup (going concern) usahanya. Kelangsungan hidup usaha selalu dihubungkan dengan kemampuan manajemen dalam mengelola perusahaan agar bertahan hidup. Keadaan dunia bisnis yang dinamis pada suatu titik dapat menghambat perkembangan perusahaan yang tidak memiliki daya saing yang kuat sehingga pada akhirnya memperlemah kondisi keuangan. Kondisi keuangan yang melemah secara menerus membuat perusahaan tersebut dipertanyakan status going concern perusahaan dan bagaimana probabilitas kebangkrutannya.

Keadaan kondisi perusahaan yang mengalami turun dan naik itu seiring berkembangnya globalisasi harus diinformasikan kepada para stakeholder perusahaan yang bersangkutan. Laporan keuangan merupakan salah satu media yang menjembatani arus informasi antara perusahaan dengan stakeholder. Salah satu tujuan laporan yang dikeluarkan perusahaan ialah untuk memberikan informasi yang akan digunakan oleh pengguna laporan untuk pengambilan keputusan (Kieso dan Weygandt 2011). Informasi tersebut akan berguna jika informasi tersebut disajikan secara berkualitas. Sebuah laporan keuangan dapat dikatakan berkualitas apabila dapat memberikan acuan yang baik pada pengguna laporan keuangan dalam melakukan sebuah tindakan terkait dalam sebuah perusahaan serta dalam keterbatasan berupa biaya dan materialitas. Kriteria acuan laporan keuangan yang baik secara fundamental dibagi menjadi dua, yaitu relevance dan reliable. Relevan berarti laporan keuangan tersebut dapat digunakan dalam proses pengambilan keputusan, sedangkan reliable berarti menggambarkan dengan jujur transaksi serta peristiwa yang terjadi serta bebas dari 
kesalahan material yang dapat menyesatkan dalam pengambilan keputusan. Sedangkan faktor faktor yang dapat meningkatkan kualitas laporan keuangan adalah understandbility, comparability, verifiabilities, dan timeliness(Kieso dan Weygandt 2011).

Konsep ketepatwaktuan (timeliness) merupakan kriteria yang harus dipenuhi agar laporan keuangan tersebut dikatakan relevan. Laporan keuangan yang dapat diakses secepatnya tidak akan kehilangan nilai ekonominya saat pengambilan keputusan. Di Indonesia, dalam rangka pemberian informasi yang tepat waktu dan akurat kepada investor mengenai kondisi keuangan emiten atau perusahaan publik, Badan Pengawas Pasar Modal dan Lembaga Keuangan (BAPEPAM dan LK), selaku lembaga yang memegang fungsi pengawasan terhadap pasar modal dan lembaga keuangan, mewajibkan kepada setiap emiten dan perusahaan publik yang telah terdaftar di Bursa Efek Indonesia (BEI) untuk menyampaikan laporan keuangan tahunan kepada BAPEPAM dan LK serta mengumumkan laporan keuangan tersebut kepada publik. Laporan keuangan tahunan tersebut wajib diumumkan kepada publik selambatlambatnya pada akhir bulan ketiga setelah tanggal laporan keuangan tahunan. Hal ini telah diatur dalam Lampiran Keputusan Ketua BAPEPAM Nomor Kep-36/PM/2003.

Berdasarkan Lampiran Keputusan Ketua BAPEPAM Nomor Kep- 36/PM/2003, laporan keuangan yang diumumkan tersebut juga harus memuat opini audit dari akuntan atas laporan keuangan yang akan memastikan bahwa laporan keuangan tersebut tidak mengandung salah saji ataupun kecurangan yang dapat merugikan kepentingan pemegang saham dan pihak lainnya yang berkepentingan. Hal ini menunjukkan bahwa ketepatan waktu suatu perusahaan publik dalam mengumumkan laporan keuangan kepada publik turut dipengaruhi oleh lamanya jangka waktu penyelesaian audit atas laporan keuangan oleh akuntan karena laporan keuangan harus telah diaudit terlebih dahulu sebelum dapat diumumkan kepada publik.
Dengan adanya batas waktu penyampaian laporan keuangan oleh BAPEPAM-LK, auditor mungkin saja menghadapi tekanan dari perusahaan untuk mempercepat auditnya dalam memenuhi batas waktu tersebut. Padahal auditor memerlukan waktu yang lebih panjang jika auditor tahu bahwa ia membutuhkan prosedur tambahan karena adanya peningkatan risiko audit dari observable karateristik audit. Ketika manajemen berniat melakukan manajemen laba dan auditor gagal mendeteksi unobservable karakteristik audit tersebut, maka pembatasan waktu audit akan memberikan manajemen peluang untuk tetap melakukan manajemen laba. Manajemen laba sebenarnya adalah hal yang wajar dilakukan di setiap perusahaan. Namun, seiring dengan terjadinya kecurangan dalam pelaporan keuangan, manajemen laba menjadi suatu hal yang bermakna negatif. Praktik manajemen laba yang tinggi akan mendistorsi kualitas akuntansi sehingga menghasilkan kualitas laba yang rendah. Akan tetapi, rendahnya manajemen laba tidak menjamin kualitas laba yang tinggi. Disisi lain, audit delay yang panjang mungkin disebabkan oleh adanya perbedaan angka antara auditor dengan klien perusahaan karena terdapat masalah dalam proses audit. Delay yang seperti itu dapat ditangkap oleh investor sebagai penurunan kualitas laporan keuangan karena investor tidak mendapatkan informasi yang diperlukan secara tepat waktu (Givoly dan Palmon 1982).

Dengan demikian, dapat disimpulkan bahwa delay yang pendek belum tentu memberikan kualitas laba yang lebih baik. Namun delay yang panjang juga belum menjamin kualitas laba yang lebih baik. Oleh karena itu, dengan alasan pentingnya kualitas laporan keuangan, maka penelitian ini bermaksud meneliti kualitas laba dari sisi dimensi timeliness dan manajemen laba. Berdasarkan penjabaran tersebut, maka penelitian ini akan meneliti pengaruh PSAK yang telah konvergen dengan IFRS dan efektif tahun 2011, kompleksitas akuntansi, dan probabilitas kebangkrutan terhadap kualitas laporan keuangan. 
TINJAUAN PUSTAKA DAN PERUMUSAN HIPOTESIS

Teori keagenan (agency theory) menyatakan bahwa tindakan manajer dipengaruhi oleh adanya konflik kepentingan antara agen (manajemen) dengan prinsipal (pemilik) yang timbul ketika setiap pihak berusaha untuk mencapai atau mempertahankan tingkat kemakmuran yang dikehendakinya. Lalu teori sinyal (signalling theory) membahas bagaimana seharusnya sinyal-sinyal keberhasilan atau kegagalan manajemen disampaikan kepada pemilik. Penyampaian laporan keuangan dapat dianggap sebagai sinyal apakah agen telah berbuat sesuai dengan kontrak. Dalam hubungan keagenan, manajer memiliki asimetri informasi terhadap pihak eksternal perusahaan seperti kreditor dan investor. Teori keagenan juga mengimpikasikan adanya asimetri informasi antara agen dan prinsipal. Asimetri informasi muncul ketika manajer sebagai agen cenderung memiliki informasi lebih banyak mengenai informasi internal dan prospek perusahaan dimasa yaang akan datang daripada informasi yang dimiliki pemegang saham atau stakeholder lainnya. Asimetri informasi dan konflik kepentingan yang terjadi antara prinsipal dan agen mendorong agen untuk menyajikan informasi yang tidak sebenarnya kepada prinsipal, terutama jika informasi tersebut berkaitan dengan pengukuran kinerja agen. Salah satu bentuk tindakan agen tersebut ialah earning management. Agar dapat meminimalkan asimetri informasi yang terjadi antara pihak manajer dan stakeholder, maka diperlukan laporan keuangan yang disampaikan secara teratur dan tepat waktu kepada stakeholder. Dalam hubungan tersebut, peran auditor diharapkan dapat menciptakan serta menerapkan sikap indepedensi untuk dapat menjadi penengah dalam menangani kepentingan tersebut.

Salah satu cara yang digunakan entitas untuk menggambarkan keadaan dan kinerjanya ke pemangku kepentingan adalah dengan melalui laporan keuangan. Pada dasarnya, tujuan laporan keuangan adalah menyediakan informasi yang menyangkut posisi keuangan, kinerja, serta perubahan posisi keuangan yang bermanfaat bagi pengguna laporan keuangan dalam pengambilan keputusan ekonomi. Berdasarkan tujuan tersebut, laporan keuangan harus memiliki kualitas informasi akuntansi yang baik. Menurut FASB, karakteristik kualitatif dari informasi akuntansi terdiri dari relevance dan reliability. Relevance yaitu mengandung unsur predictive value, feedback value, dan timeliness. Reliability yaitu mengandung unsur verifiable, faithful representation, neutrality, comparibility dan consistency. Sedangkan menurut IASB, karakteristik kualitatif dari informasi akuntansi ialah understandability, relevance, reliable, dan omparability. Unsur relevance dari IASB mengandung unsur materialitas dan ketepatwaktuan (timelines).

Ketepatan waktu atau timeliness dari laporan keuangan merupakan salah satu elemen karakteristik kualitatif laporan keuangan yang baik dan berguna untuk pengambilan keputusan. Laporan keuangan yang tepat waktu berarti laporan tersebut tersedia bagi para pengambil keputusan sebelum informasi dari laporan tersebut kehilangan kapasitasnya untuk mempengaruhi keputusan. Jika pengambil keputusan memiliki informasi relevan lebih awal, maka semakin besar kapasitas laporan keuangan untuk mempengaruhi pengambilan keputusan. Dan laporan keuangan yang tidak memenuhi ketepatwaktuannya akan kehilangan kegunaannya. Ketepatan waktu tidak menjamin relevansi, namun relevansi tidaklah mungkin tanpa ketepatwaktuan. Oleh karena itu, ketepatanwaktuan merupakan batasan yang penting pada publikasi laporan keuangan dan sebagai salah satu kriteria pendukung dari sifat kerelevanan. Proses siklus akuntansi harus dilakukan secepat mungkin untuk menjamin ketersediaan informasi ditangan pemakai laporan keuangan. Ketepatan waktu mengimpikasikan bahwa laporan keuangan seharusnya disajikan pada suatu interval waktu untuk menjelaskan perubahan dalam perusahaan yang akan mempengaruhi pemakai informasi dalam membuat prediksi dan keputusan.

Schwartz dan Soo (1996) mengukur timeliness pelaporan berdasarkan pada kepa- 
tuhan perusahaan dalam mematuhi peraturan pelaporan informasi keuangan yang ditetapkan oleh Stock Exchange Commision. Aktas dan Kargin (2011) berargumen bahwa informasi harus disampaikan sedini mungkin untuk dapat digunakan sebagai dasar untuk membantu dalam pengambilan keputusan ekonomi dan untuk menghindari tertundanya pengambilan keputusan tersebut.

Salah satu cara melihat kualitas laporan keuangan adalah dengan cara melihat kualitas laba yang dilaporkan. Manajemen laba adalah salah satu faktor yang mempengaruhi kualitas laba. Laba yang memiliki tingkat manajemen laba yang abnormal adalah laba yang tidak berkualitas. Scott (2009) mendefinisikan manajemen laba adalah pilihan yang diambil manajemen terkait kebijakan akuntansi ataupun tindakan yang mempengaruhi laba yang dilakukan untuk mencapai beberapa tujuan khusus dari pelaporan laba.

Menurut Scott (2009), manajemen laba dapat dipandang melalui dua perspektif yaitu perspektif kontraktual (contractual perspective) dan perspektif pelaporan keuangan (financial reporting perspective). Dari perspekif kontraktual, manajemen laba dapat digunakan sebagai cara yang paling mudah dilakukan untuk melindungi perusahaan terhadap konsekuensi dari kejadian-kejadian yang tidak terlihat ketika kontrak sangat kaku dan tidak lengkap. Sedangkan melalui perspekif pelaporan keuangan, manajer dapat mempengaruhi nilai pasar saham dengan melakukan manajemen laba. Manajemen laba dapat memberikan informasi terhadap pasar dan memungkinkan perusahaan mengkomunikasikan laba yang diharapkan secara terus menerus.

Berdasarkan kedua perspektif yang dikemukakan oleh Scott (2009), manajemen laba merupakan suatu alat yang 'baik' bagi perusahaan. Akan tetapi, praktik manajemen laba yang terlalu banyak dapat mengurangi kegunaan informasi keuangan bagi investor. Hal ini terutama bila manajemen laba dilakukan pada sektor pendapatan utama atau pengungkapan yang tidak sempurna. Manajemen laba juga mempengaruhi motivasi manajer untuk memberikan usaha, karena manajer dapat menggunakan manajemen laba untuk memperlancar kompensasi mereka sepanjang waktu dan dengan demikian mengurangi risiko kompensasi. Semakin fluktiatif laba bersih yang dilaporkan, semakin tinggi kemungkinan terjadinya pelanggaran kontrak. Hal ini akan memberikan insentif bagi manajer untuk melakukan manajemen laba sehingga perusahaan dapat mempertahankan rasio keuangan dari waktu ke waktu. Selain itu, manajer melakukan manajemen laba untuk kepentingan pelaporan terhadap pihak eksternal.

Schipper (1989) mendefinisikan manajemen laba sebagai suatu intervensi yang memiliki tujuan tertentu dalam proses pelaporan keuangan eksternal demi mendapatkan keuntungan pribadi baik bagi manajer maupun pemegang saham. Menurut Healy dan Wahlen (1999), manajemen laba terjadi ketika manajer menggunakan judgement dalam pelaporan keuangan dan penyusunan transaksi untuk merubah laporan keuangan, yang dipertanggungjawaban kepada para stakeholder terkait performa ekonomi perusahaan, atau untuk memepengaruhi hasil kontraktual yang bergantung pada angka akuntansi yang dilaporkan.

\section{Pengaruh Konvergensi IFRS Efektif 2011 terhadap Timeliness dan Manajemen Laba}

Yaacob dan Che-Amed (2012) menemukan bahwa IFRS sebagai regulasi yang baru diterapkan akan meningkatkan audit timeliness. Penelitian ini juga membuktikan bahwa secara umum IFRS merupakan standar yang kompleks, dimana kompleksitasnya tidak hanya terletak di perlakuan akuntansi tetapi juga terletak pada kesulitan yang melekat pada pelaporan dan pengungkapan yang mendetil dan lengkap.

Dengan demikian, terdapat effort lebih dalam beberapa area pekerjaan terkait penerapan IFRS. IFRS, yang lebih menekankan pada principled based, penggunaan fair value, dan pengungkapan yang detil baik secara kuantitatif dan kualitatif membuat penyusunan laporan keuangan membutuhkan judgement. Dengan adanya judgement tersebut dan per- 
ubahan yang signifikan di beberapa area sebelumnya, penerapan PSAK efektif di tahun 2011 yang telah konvergen dengan IFRS mebuat persiapan laporan keuangan oleh manajemen menjadi lebih lama serta meningkatkan resiko audit dalam proses auditnya. Akibatnya, auditor memerlukan waktu yang lebih banyak dalam memverifikasi penilaian yang diberikan akuntan dalam laporan keuangan. Auditor juga perlu waktu untuk menelusuri bukti audit sehingga akan memperpanjang waktu untuk mengeluarkan laporan audit.

$\mathrm{H}_{1 \mathrm{a}}$ : Konvergensi IFRS dalam PSAK yang efektif tahun 2011 berpengaruh positif terhadap audit delay dan report delay

Glaum et al. (2008), yang meneliti pengaruh adopsi IFRS di Jerman terhadap kecendrungan manajemen laba, menemukan bahwa adopsi IFRS menurunkan intensitas manajemen laba dibandingkan saat menggunakan local GAAP. Hal ini didukung pula dengan penelitian Chen et al. (2010) yang meneliti pengaruh IFRS terhadap kualitas akuntansi di negara-negara Uni Eropa. Penelitian ini menunjukkan bahwa terjadi peningkatan kualitas akuntansi setelah pengadopsian IFRS di Uni Eropa. Hal ini ditunjukkan dengan lebih sedikitnya pengaturan laba dengan target tertentu dan absolute discretionary accrual yang jauh lebih rendah.

Dengan demikian, dapat disimpulkan bahwa konvergensi IFRS yang terefleksikan dalam 16 PSAK efektif 2011 menurunkan manajemen laba dan meningkatkan kualitas laporan keuangan. IFRS yang lebih meminta pengungkapan yang lebih detil dibanding standar sebelumnya membuat manajemen harus mengungkapkan segala transaksi yang sebelumnya off-balance sheet. Pengungkapan yang lebih detil juga mengurangi adanya asimetri informasi sehingga meningkatkan kualitas laba (Zhou dan Lobo 2008) Dengan demikian dapat disimpulkan bahwa perilaku manajemen laba diduga menjadi lebih sulit saat periode PSAK yang telah konvergen dengan IFRS dan efektif tahun 2011 diban- dingkan dengan PSAK sebelumnya yang belum konvergen dengan IFRS.

$\mathrm{H}_{1 \mathrm{~b}}$ : Konvergensi IFRS dalam PSAK yang efektif tahun 2011 berpengaruh negatif terhadap tingkat manajemen laba

\section{Pengaruh Kompleksitas Akuntansi ter- hadap Timeliness dan Manajemen Laba}

$\mathrm{Ng}$ dan Tai (1994) menemukan bahwa perusahaan dengan jumlah anak perusahaan yang besar akan memiliki audit delay yang lebih panjang karena memiliki tingkat kompleksitas akuntansi dan audit yang lebih tinggi. Tingkat kompleksitas dari operasi perusahaan, yang bergantung pada jumlah dan lokasi dari unit operasinya (cabang) dan diversifikasi produk dan pasar, diduga akan mempengaruhi lama waktu auditor untuk menyelesaikan auditnya yang pada akhirnya mempengaruhi lama waktu perusahaan mempublikasikan laporan keuangannya ke publik.

Oleh karena itu, diduga ada hubungan positif antara kompleksitas akuntansi dan audit delay. Hipotesis ini didukung oleh Ashton et al. (1987) yang menemukan hubungan positif signifikan antara kompleksitas operasional dari perusahaan dan audit delay. Dalam Bamber et al. (1993), kompleksitas dari operasional perusahaan diukur dari jumlah lini bisnis yang berbeda yang beroperasi pada sampel perusahaan.

$\mathrm{H}_{2 \mathrm{a}}$ : Kompleksitas akuntansi yang diukur dengan jumlah anak perusahaan memperpanjang audit dan report delay.

Dyreng et al. (2011) menemukan bahwa manajer perusahaan dengan anak perushaan yang tersebar area geografisnya cenderung melakukan manajemen laba yang lebih tinggi. Ketika manajer memutuskan untuk melakukan manajemen laba, mereka perlu memutuskan untuk melakukan manajemen laba di tingkat pendapatan domestik, pendapatan asing atau keduanya. Manajer diduga juga mempertimbangkan cost dan benefit saat akan melakukan manajemen laba seperti kecenderungan ketahuan serta kompensasi bonus yang akan didapat. 
Thomas et al. (2004) menemukan bahwa perusahaan yang memiliki anak perusahaan yang lebih banyak cenderung melakukan manajemen laba lebih agresif melalui transaksi dengan pihak-pihak yang memiliki hubungan istimewa dengannya. Ketika perusahaan induk memiliki hubungan dominan dengan perusahaan afiliasi, perusahaan induk dapat mengatur atau menstruktur transaksi antara perusahaannya dengan pihak afiliasinya sehingga perusahaan dapat mencapai target pelaporan laba.

Dengan demikian dapat disimpulkan bahwa perusahaan dengan anak perusahaan yang banyak akan meningkatkan kompleksitas organisasi dan kemudian meningkatkan asimetri informasi antara manajer dan investor. Asimetri informasi seperti ini dapat membuka peluang melakukan manajemen laba karena investor mungkin tidak memiliki insentif, sumber daya dan akses yang cukup untuk memantau tindakan manajer (Warfield et al. 1995)

$\mathrm{H}_{2 \mathrm{~b}}$ : Kompleksitas akuntansi yang diukur dengan jumlah anak perusahaan berhubungan postif dengan manajemen laba

\section{Pengaruh Probabilitas Kebangkrutan terhadap Timeliness dan Manajemen Laba}

Perusahaan yang diduga memiliki probabilitas kebangkrutan yang lebih besar cenderung akan mengalami audit delay yang lebih panjang. Perusahaan yang mengalami kesulitan keuangan cenderung akan menunda pelaporan keuangan karena auditor memerlukan waktu yang lebih lama dalam proses audit serta membutuhkan data tambahan untuk dapat menghasilkan opini yang sesuai dengan kondisi perusahaan tersebut. Hal ini didukung oleh penelitian sebelumnya (Bamber et al., 1993; Jaggi dan Tsui 1999; Schwartz dan Soo 1996; Habib dan Bhuiyan 2011) yang menemukan bahwa kesulitan keuangan dengan menggunakan proksi probabilitas kebangkrutan berpengaruh terhadap audit delay. Dengan demikian, semakin rendah (besar) nilai dari Altman Z-Score, maka semakin tinggi (rendah) kemungkinan terjadinya kegagalan dan semakin buruk (bagus) kondisi keuangan perusahaan. Kondisi keuangan perusahaan yang buruk akan membuat auditor meningkatkan resiko auditnya dan kemudian memperpanjang waktu audit delay.

$\mathrm{H}_{3 \mathrm{a}}$ : Probabilitas kebangkrutan berhubungan positif dengan audit dan reporting delay

Kegagalan perusahaan menimbulkan biaya ekonomi dan sosial yang besar dan mepengaruhi banyak pihak (investor, kre ditor, manajemen dan karyawan) (Charitou et al. 2007). Hal ini menyebabkan manajer pada perusahaan yang mengalami tekanan keuangan (financial distressed) mungkin akan memanipulasi laporan keuangan perusahaan untuk menutupi atau menunda kondisi kesulitan keuangan perusahaan (Charitou et al. 2007). Sweeney (1994) menemukan bahwa perusahaan dalam keadaan distressed akan melakukan pilihan memanipulasi laba untuk menghindari pelanggaran perjanjian hutang. Sedangkan penelitian lain menemukan bahwa perusahaan dengan masalah perjanjian hutang akan menggunakan akrual diskresioner manajemen yang lebih tinggi akibat adanya kesulitan keuangan (DeFond dan Jiambalvo 1994; Dichev dan Skinner 2002). Sebaliknya, DeAngelo et al. (1994), dalam penelitiannya pada perusahaan terdaftar di NYSE, menemukan bahwa para manajer perusahaan yang mengalami kerugian dan pengurangan dividen secara persisten cenderung melakukan income -decreasing untuk mendapatkan kontrak yang lebih baik selama renegoisiasi hutang.

Penelitian penelitian ini menunjukan manajemen melakukan manajemen laba untuk menutup-nutupi kondisi keuangan perusahaan ataupun menghindari pelanggaran perjanjian hutang, ataupun untuk keberhasilan renegosiasi hutang. Arah manajemen laba apakah menaikan atau menurunkan laba terhantung dari insentif yang dimiliki oleh manajemen. Oleh karena itu, dapat disimpulkan bahwa perusahaan yang mengalami financial distressed akan melakukan manajemen laba baik yang sifatnya menaikan ataupun menurunkan laba. $\mathrm{H}_{3 \mathrm{~b}}$ : Probabilitas kebangkrutan berhubungan positif dengan manajemen laba. 
Karena arah manajemen laba yang dilakukan perusahaan dalam kesulitan keuangan dapat menaikan atau menurunkan laba maka dalam penelitian ini tidak dibedakan arah manajemen laba perusahaan. Pengukuran manajemen laba yang digunakan adalah nilai absolut dari akrual diskresioner.

\section{METODA PENELITIAN Model Penelitian}

Model 1 untuk menguji hipotesis 1a, 2a, dan $3 a$

Model 1a:

$$
\begin{aligned}
A R L_{i t}=\alpha+ & \beta_{1} P_{S A K_{i t}}+\beta_{2} \text { COMPLX } \\
& +\beta_{3} B_{i t} \text { CON } \\
& +\beta_{4} G R A Y A R E A+\beta_{5} S I Z E_{i t} \\
& +\beta_{6} C_{\text {COOE }}+\beta_{7} \text { KAP }_{i t}+e_{i t}
\end{aligned}
$$

Model 1b:

$$
\begin{aligned}
\operatorname{INTRM}_{i t}=\alpha & +\beta_{1} \text { PSAK }_{i t}+\beta_{2} \text { COMPLX }_{i t} \\
& +\beta_{3} \text { BANCR }_{i t} \\
& +\beta_{4} \text { GRAYAREA }+\beta_{5} \text { SIZE }_{i t} \\
& +\beta_{6} \text { CROE }_{i t}+\beta_{7} \text { KAP }_{i t}+e_{i t}
\end{aligned}
$$

Model 1c:

$$
\begin{aligned}
\text { TPERIOD }_{i t}= & \alpha+\beta_{1} \text { PSAK }_{i t} \\
& +\beta_{2} \text { COMPLX }_{i t}+\beta_{3} \text { BANCR }_{i t} \\
& +\beta_{4} \text { GRAYAREA }+\beta_{5} \text { SIZE }_{i t} \\
& +\beta_{6} \text { CROE }_{i t}+\beta_{7} \text { KAP }_{i t}+e_{i t}
\end{aligned}
$$

Hipotesis penelitian yang telah dikemukan sebelumnya dapat disajikan dalam bentuk hipotesis statistik sebagai berikut

$$
\mathrm{H}_{1} \mathrm{a}: \beta_{1}>0, \mathrm{H}_{2} \mathrm{a}: \beta_{2}>0, \mathrm{H}_{3} \mathrm{a}: \beta_{3}>0
$$

Dimana:

$\alpha=$ Intercept

$\mathrm{ARL}=$ jumlah hari dari tanggal berakhirnya laporan keuangan hingga tanggal tanda tangan opini

INTRM = jumlah hari dari tanggal tanda tangan opini hingga tanggal publikasi di BEI

TPERIOD = jumlah hari dari tanggal berakhirnya laporan keuangan hingga tanggal publikasi.

PSAK = Konvergensi IFRS dalam PSAK Efektif 2011 (beri nila 1 untuk tahun 2011 dan beri 0 jika tidak)
COMPLX $=$ Jumlah anak perusahaan pada tahun $\mathrm{t}$

BANCR $=$ Variabel dummy, 1 jika perusahaan memiliki nilai Altman Z Score di bawah 1.81 dan 0 jika bukan

GRAYAREA = Variabel dummy, 1 jika perusahaan memiliki nilai Altman $\mathrm{Z}$ Score antara 1.81-2.9 dan 0 jika bukan

SIZE $=$ Log natural dari total asset pada tahun $\mathrm{t}$ $\mathrm{CROE}=\mathrm{ROE}$ tahun sekarang- ROE tahun sebelumnya

$\mathrm{KAP}=$ Beri nilai 1 jika auditor dari BIG4, beri nilai 0 jika lainnya

$\mathrm{E}=$ Error

\section{Model 2 untuk menguji hipotesis $1 b, 2 b$, dan}

$3 b$

Model 2:

$$
\begin{aligned}
D A C_{i t}=\alpha+ & \beta_{1} P_{S A K_{i t}}+\beta_{2} \text { COMPLX } \\
& +\beta_{3} \text { BANCR }_{i t} \\
& +\beta_{4} \text { GRAYAREA }_{i t}+\beta_{5} \text { SIZE }_{i t} \\
& +\beta_{6} \text { KAP }_{i t}+\beta_{7} \text { CFO } \\
& +\beta_{8} \text { GROWTH }_{i t}+e_{i t}
\end{aligned}
$$

Hipotesis penelitian yang telah dikemukan sebelumnya dapat disajikan dalam bentuk hipotesis statistik sebagai berikut:

$$
\mathrm{H}_{1} \mathrm{~b}: \beta_{1}<0, \mathrm{H}_{2} \mathrm{~b}: \beta_{2}>0, \mathrm{H}_{3} \mathrm{~b}: \beta_{3}>0
$$

dimana:

DAC $=$ tingkat akrual diskresioner perusahaan i pada tahun $t$ yang telah diabsolutkan

$\mathrm{CFO}=$ arus kas operasi dibagi total aset pada tahun $\mathrm{t}$

GROWTH $=$ pertumbuhan perusahaan yang diukur dengan persentase perubahan penjualan tahun $\mathrm{t}$ dibandingkan tahun $\mathrm{t}-1$

\section{Operasionalisasi Variabel}

Variabel Dependen dalam penelitian ini adalah audit dan report delay dan tingkat manajemen laba, Konvergensi IFRS dalam PSAK Efektif 2011, Kompleksitas Akuntansi, dan probabilitas kebangkrutan. Penjelasan operasionalisasi variabel dapat dilihat pada tabel 1 berikut. 


\section{Tabel 1: Operasionalisasi Variabel Utama}

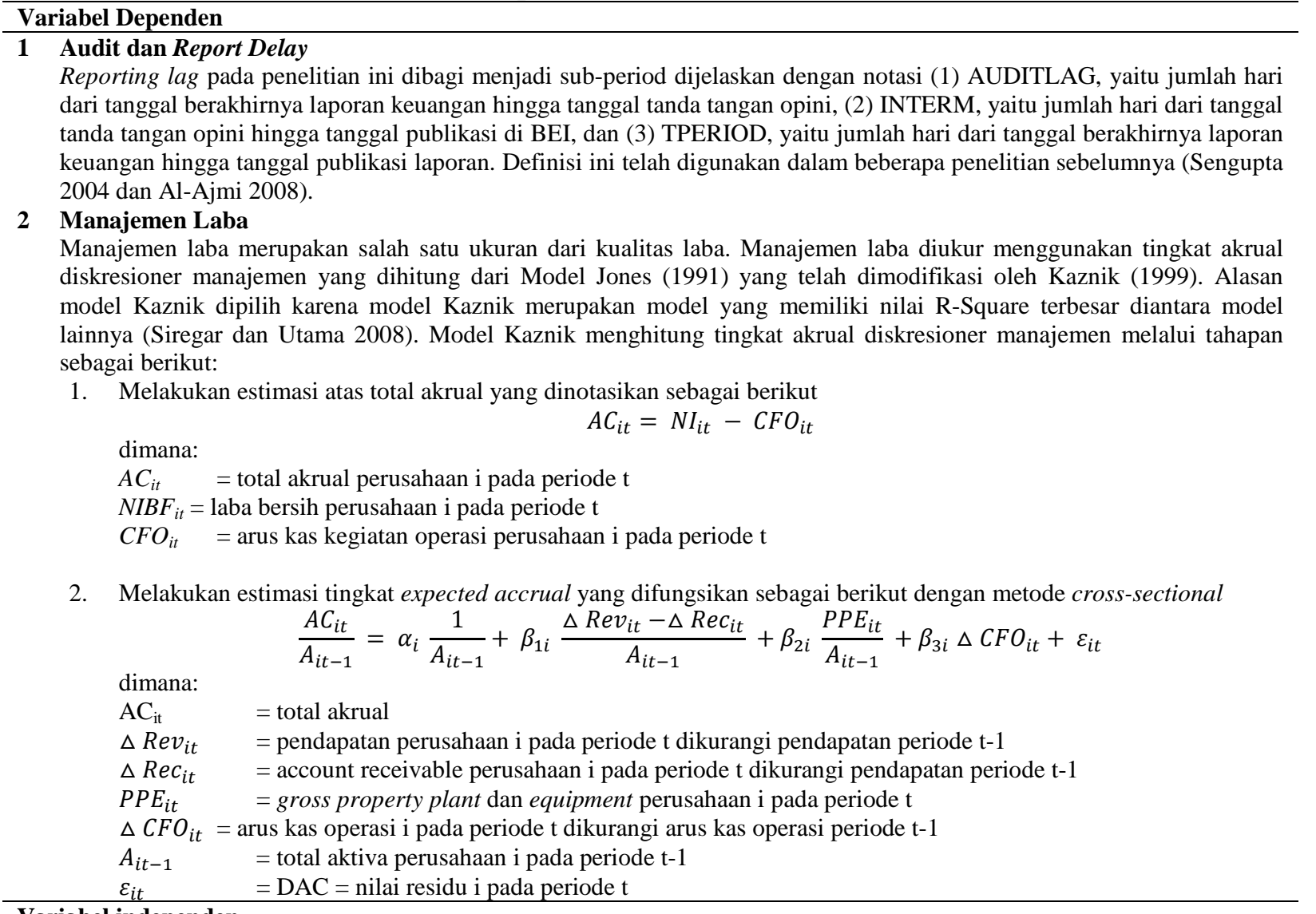

\section{Variabel independen}

\section{Konvergensi IFRS dalam PSAK Efektif 2011}

Penelitian sebelumnya yang dijadikan acuan dalam penelitian ini ialah Habib dan Bhuiyan (2011). Adopsi IFRS diproksikan menggunakan variabel dummy tahun pengimplementasian. Angka 1 akan diberikan untuk perusahaan yang telah mengadopsi IFRS pada PSAK. Karena IFRS di Indonesia dilakukan secara bertahap dan penelitian ini hanya berfokus pada PSAK yang efektif di tahun 2011, maka pemberian variabel dummy didasari dengan tahun sebelum dan sesudah efektifnya PSAK yang telah konvergen dengan IFRS di tahun 2011. Perusahaan pada tahun 2011 diberikan nilai 1 sedangkan perusahaan pada tahun 2010 diberikan nilai 0 .

PSAK yang telah konvergen dengan IFRS dan efektif di tahun 2011 adalah PSAK No 1 (Penyajian Laporan Keuangan), PSAK No 2 (Laporan Arus Kas), PSAK No 3 (Laporan Keuangan Interim), PSAK No 4 (Laporan Keuangan Konsolidasian dan Laporan Keuangan Tersendiri), PSAK No 5 (Segmen Operasi), PSAK No 7 (Pengungkapan Pihak Pihak Relasi), PSAK No 8 (Peristiwa setelah Periode Pelaporan), PSAK No 12 (Bagian Partisipasi dalam Ventura Bersama), PSAK No 15 (Investasi pada Entitas Asosiasi), PSAK No 19 (Aset Tak Berwujud), PSAK No 22 (Kombinasi Bisnis), PSAK No 23 (Pendapatan), PSAK No 25 (Kebijakan Akuntansi, Perubahan Estimasi Akuntansi dan Kesalahan), PSAK No 48 (Penurunan Nilai Aset), PSAK No 57 (Provisi, Liabilitas Kontijensi, dan Aset Kontijensi), dan PSAK No 58 (Aset Tidak Lancar Dimiliki untuk Dijual dan Operasi yang Dihentikan)

\section{Kompleksitas Akuntansi}

Kompleksitas akuntansi pada penelitian ini juga mengacu pada penelitian Yaacob dan Che Ahmad (2012) yang diukur dengan jumlah anak perusahaan yang dimiliki oleh perusahaan. Perusahaan dengan jumlah anak perusahaan yang besar akan memiliki tingkat kompleksitas akuntansi yang tinggi pada saat konsolidasi laporan keuangan. Akibatnya, tingkat kompleksitas audit juga akan lebih tinggi sehingga akan memiliki waktu audit delay yang lebih panjang (Ng and Tai 1994). Perusahaan dengan anak perusahaan yang banyak juga meningkatkan kompleksitas organisasi dan kemudian meningkatkan asimetri informasi antara manajer dan investor. Asimetri informasi seperti ini dapat membuka peluang melakukan manajemen laba karena investor mungkin tidak memiliki insentif, sumber daya dan akses yang cukup untuk memantau tindakan manajer (Warfield 1995)

\section{Status Probabilitas Kebangkrutan}

Probabilitas kebangkrutan adalah kemungkinan yang tejadi pada perusahaan akibat adanya kesulitan keuangan yang jika sangat parah dapat mengakibatkan kebangkrutan. Pada penelitian ini, peneliti akan menggunakan model probabilitas kebangkrutan Altman Z-Score karena model ini merupakan model terbaik yang dapat memprediksi kebangkrutan pada perusahaan Indonesia dibandingkan model kebangkrutan Zmijewski dan Springate (Setyarno et al. 2006; Hadi dan Anggraini 2008). Selain itu, Model Atman merupakan model yang telah diterima dan digunakan secara luas oleh para auditor dalam menilai ketepatan pemberian opini going concern (Fanny dan Saputra 2005). Altman Z-Score dihitung dengan cara sebagai berikut: 
$\mathrm{Z}$-Score $=1,2 \mathrm{~T}_{1}+1,4 \mathrm{~T}_{2}+3,3 \mathrm{~T}_{3}+0,6 \mathrm{~T}_{4}+0,999 \mathrm{~T}_{5}$

Keterangan:

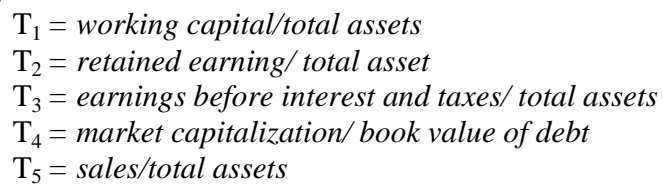

Dari hasil analisa model altman tersebut, akan diperoleh Z-score dimana:

- $\quad$ Perusahaan sehat jika $Z>2,99$

- $\quad$ Perusahaan berada di daerah rawan jika $Z=1,81-2,99$

- Perusahaan bangkrut jika $\mathrm{Z}<1,81$

Semakin rendah (besar) nilai dari Z-Score, maka semakin tinggi (rendah) kemungkinan terjadinya kegagalan dan semakin buruk (bagus) kondisi keuangan perusahaan. Kondisi keuangan perusahaan yang buruk akan membuat auditor meningkatkan resiko auditnya dan kemudian memperpanjang waktu audit delay. Kondisi keuangan yang buruk akan mendorong perusahaan untuk melakukan income-increasing accrual karena manajer mempunyai motivasi yang kuat untuk memanipulasi kinerja opersional perusahaan yang buruk (Burgstahler dan Dichev 1997). Disisi lain, perusahaan akan menggunakan decreasing accrual agar dapat melakukan renegosiasi kontrak utang (DeAngelo et al, 1994). Pada penelitian ini peneliti menggunakan variable dummy BANCR dimana 1 untuk perusahaan memiliki probabilitas Altman Z-Score dibawah 1.81 dan 0 jika bukan. Sedangkan variable dummy GRAYAREA dimana 1 untuk perusahaan yang masuk ke daerah rawan, yaitu dengan nilai Altman Z Score antara 1.81 hingga 2.9, dan 0 jika bukan.

\section{Variabel Kontrol}

Variabel kontrol yang digunakan untuk model audit dan report delay adalah ukuran perusahaan, good and bad news, dan ukuran KAP. Sedangkan variabel kontrol untuk model manajemen laba ialah variabel ukuran perusahaan, ukuran KAP, arus kas operasi dan pertumbuhan penjualan. Penjelasan variabel kontrol beserta operasionalisasinya dapat dilihat pada tabel 2 .

Tabel 2: Variabel kontrol model penelitian

\begin{tabular}{ll}
\hline Variabel & Penjelasan \\
\hline Ukuran Perusahaan & Ukuran perusahaan dapat memiliki hubungan positif maupun \\
& negatif terhadap audit dan report delay maupun manajemen laba. \\
& Perusahaan yang relatif besar memiliki sistem kontrol internal yang \\
& lebih baik pada perusahan besar sehingga dapat mengurangi \\
& kecenderungan terjadinya error dalam laporan keuangan. Hal \\
& tersebut juga memungkinkan auditor untuk mengandalkan sistem \\
& kontrol internal perusahaan lebih ekstensif dan lebih banyak \\
& melakukan kerja interim sehinga auditor dapat mengurangi \\
& pekerjaan audit pada akhir periode pelaporan (Carslaw dan Kaplan \\
& 1991). Di lain pihak, perusahaan besar cenderung lebih bergantung \\
& pada pembiayaan dari luar perusahaan sehingga lebih sensitif \\
& terhadap kebutuhan investor akan prosedur audit yang dilakukan \\
& untuk menjamin laporan keuangan perusahaan. Kompleksitas bisnis \\
& dan operasional perusahaan besar juga menyebabkan kompleksitas \\
& audit yang lebih tinggi sehingga memperpanjang waktu audit yang \\
& diperlukan (Al-Ajmi 2008). \\
& Perusahaan besar juga memiliki sistem pengendalian \\
& internal dan audit internal yang lebih kompeten dibandingkan \\
& perusahaan kecil sehingga mengurangi tingkat manajemen laba \\
& (Kim et al, 2003). Perusahaan besar juga cenderung memiliki risiko \\
& litigasi yang lebih besar sehingga memotivasi perusahaan besar \\
& untuk meningkatkan transparansi dalam pelaporan keuangan. Di \\
& lain pihak, Moses (1987) menemukan bahwa perusahaan besar \\
& memiliki peluang yang lebih tinggi untuk meningkatkan laba secara \\
& artifisial karena kompleksitas bisnis dan operasionalnya \\
& menyulitkan pengguna laporan keuangan untuk mendeteksi \\
& manipulasi tersebut. Semakin besar perusahaan, semakin kompleks \\
& bisnis dan operasional dan semakin rumit sistem informasi sehingga \\
& kemungkinan auditor mendeteksi manipulasi laba yang dilakukan \\
& oleh manajemen berkurang..
\end{tabular}

Operasionalisasi Variabel Ukuran perusahaan akan diukur dengan menggunakan logaritma natural dari total aset perusahaan. 


\begin{tabular}{|c|c|c|}
\hline Variabel & Penjelasan & Operasionalisasi Variabel \\
\hline Good and Bad News & $\begin{array}{l}\text { Perusahaan yang mengalami kenaikan profitabilitas yang tinggi } \\
\text { cenderung akan mempercepat publikasi laporan keuangannya } \\
\text { karena hal tersebut merupakan kabar baik, sedangkan perusahaan } \\
\text { yang mengalami kerugiannya akan menunda publikasi laporan } \\
\text { keuangannya (Givoly and Palmon 1982; Haw et al., 2000). }\end{array}$ & $\begin{array}{l}\text { Penelitian ini akan menggunakan } \\
\text { variabel profitabilitas dengan } \\
\text { proksi perubahan dari nilai ROE } \\
\text { dari tahun sebelumnya. }\end{array}$ \\
\hline Arus Kas Operasi & $\begin{array}{l}\text { Variabel ini dimasukkan untuk mengontrol tingkat kinerja yang } \\
\text { ekstrim dari perusahaan karena arus kas operasional digunakan } \\
\text { untuk estimasi yang bersifat non-discretionary accrual yang juga } \\
\text { menentukan besarnya laba yang akan diperoleh. Semakin tinggi kas } \\
\text { operasi menunjukkan kesempatan untuk memperoleh laba besar } \\
\text { sehingga manajemen laba akan dilakukan pada kas operasi. } \\
\text { Perusahaan dengan arus kas operasi yang tinggi cenderung } \\
\text { memiliki total akrual rendah sehingga mengurangi tingkat } \\
\text { discretionary accrual (Dechow et al, 1995). }\end{array}$ & $\begin{array}{l}\text { Arus kas operasi merupakan nilai } \\
\text { bersih kas yang dihasilkan dari } \\
\text { kegiatan operasi perusahaan pada } \\
\text { akhir tahun yang bersangkutan } \\
\text { dibagi dengan total asset } \\
\text { perusahaan pada akhir tahun } \\
\text { yang sama. }\end{array}$ \\
\hline Growth & $\begin{array}{l}\text { Summers dan Sweeney (1998) menemukan bahwa perusahaan } \\
\text { dengan pertumbuhan yang tinggi cenderung melakukan manajemen } \\
\text { laba ketika pertumbuhan melambat untuk mempertahankan } \\
\text { konsistensi pertumbuhan perusahaan. }\end{array}$ & $\begin{array}{l}\text { persentase perubahan nilai } \\
\text { penjualan perusahaan pada tahun } \\
\text { yang bersangkutan dibandingkan } \\
\text { dengan tahun sebelumnya. }\end{array}$ \\
\hline Ukuran KAP & $\begin{array}{l}\text { KAP yang memiliki hubungan kerjasama dengan The Big Four } \\
\text { diharapkan memiliki kompetensi dan kualitas yang lebih baik } \\
\text { sehingga dapat menyelesaikan proses audit lebih cepat (Leventis et } \\
\text { al, 2005). Selain itu, KAP yang berafiliasi dengan The Big Four juga } \\
\text { diasumsikan memiliki kualitas audit yang lebih baik sehingga dapat } \\
\text { mendeteksi tingkat manajemen laba yang dilakukan perusahaan } \\
\text { (Francis } \text { et al, 1999). }\end{array}$ & $\begin{array}{l}\text { Variabel ukuran KAP akan } \\
\text { diukur menggunakan variabel } \\
\text { dummy dimana KAP yang } \\
\text { bekerja sama dengan The Big } \\
\text { Four akan diberi kode } 1 \text { sedang- } \\
\text { kan KAP lainnya akan diberi } \\
\text { kode } 0 \text {. }\end{array}$ \\
\hline
\end{tabular}

\section{Metoda Pengolahan Data}

Pengolahan data akan dilakukan dengan menggunakan software Microsoft excel dan Stata 12.0. Microsoft excel akan digunakan sebagai media pengumpulan data baik variabel dependen maupun independen. Stata 12.0 akan digunakan untuk menjalankan multiple regression. Adapun langkah-langkah yang akan dilakukan meliputi uji pemilihan model data panel, uji statistik dan uji ekonometrika.

\section{HASIL DAN PEMBAHASAN Deskripsi Sampel Penelitian}

Sampel yang digunakan dalam penelitian ini berasal dari data laporan tahunan yang terdaftar pada Bursa Efek Indonesia (BEI) pada tahun 2010-2011. Penelitian mengeluar- kan perusahaan dalam industri keuangan dari sampel karena perusahaan industri keuangan memiliki karakteristik yang unik dan merupakan high regulated company. Proses penetapan sampel diringkas dalam tabel 3.

\section{Statistik Deskriptif}

Tabel 4 menyajikan statistik deskriptif tentang variabel yang digunakan. Untuk variabel PSAK yang menggunakan variabel dummy tahun, rata-rata besaran akrual diskresioner di tahun 2010 lebih besar dibandingkan rata-rata besaran akrual diskresioner pada tahun 2011. Sedangkan rata-rata audit dan report delay di tahun 2010 lebih pendek dibandingkan ratarata audit dan report delay pada tahun 2011.

Tabel 3: Pemilihan Sampel

\begin{tabular}{lc}
\hline \multicolumn{1}{c}{ Deskripsi } & Jumlah \\
\hline $\begin{array}{l}\text { Perusahaan yang terdaftar di BEI selama tahun 2010-2011 } \\
\text { (non keuangan) }\end{array}$ & 345 \\
Perusahaan dengan tanggal neraca selain 31 Desember & $(4)$ \\
Perusahaan sampel & 341 \\
Jumlah observasi dalam rentang waktu dua tahun penelitian & 682 \\
Perusahaan dengan data tidak lengkap & $(74)$ \\
Observasi yang teridentifikasi sebagai outlier & $(68)$ \\
Jumlah observasi & $\mathbf{5 4 0}$ \\
\hline
\end{tabular}

Sumber: data diolah, 2012 
Tabel 4: Statistik Deskriptif Variabel Penelitian

\begin{tabular}{|c|c|c|c|c|c|}
\hline Variabel & $\mathbf{N}$ & Mean & Std Dev & Min & Max \\
\hline$\overline{\mathrm{ARL}}$ & 540 & 76.659 & 19.779 & 12 & 123 \\
\hline INTRM & 540 & 15.944 & 15.700 & 2 & 47 \\
\hline TPERIOD & 540 & 92.467 & 18.432 & 24 & 132 \\
\hline DAC & 540 & 0.069 & 0.062 & 0.004 & 0.229 \\
\hline COMPLX & 540 & 7.100 & 8.008 & 0 & 35 \\
\hline CROE & 540 & 0.003 & 0.993 & -0.210 & 0.239 \\
\hline SIZE (Rp) & 540 & $4,114,475 \mathrm{jt}$ & 7,405,617 jt & $11,767 \mathrm{jt}$ & $57,773,110 \mathrm{jt}$ \\
\hline CFO & 540 & 0.078 & 0.108 & -0.247 & 0.403 \\
\hline GROWTH & 540 & 0.254 & 0.466 & -0.668 & 0.996 \\
\hline \multicolumn{2}{|c|}{ Dummy Variabel } & Prop: 1 & \begin{tabular}{|l|} 
Prop: 0 \\
\end{tabular} & & \\
\hline PSAK & 540 & $50 \%$ & $50 \%$ & & \\
\hline KAP & 540 & $37.60 \%$ & $62.40 \%$ & & \\
\hline BANCR & 540 & $16.40 \%$ & $83.50 \%$ & & \\
\hline GRAYAREA & 540 & $26.30 \%$ & $73.70 \%$ & & \\
\hline
\end{tabular}

\section{Hasil Pengujian Hipotesis}

Hasil pengujian hipotesis ditunjukan di table 5 dan table 6. Tabel 5 merupakan hasil pengujian dampak konvergensi IFRS efektif 2011, kompleksitas akuntansi, dan probabilitas kebangkrutan terhadap timeliness laporan keuangan. Sedangkan tabel 6 merupakan hasil pengujian dampak konvergensi IFRS efektif 2011, kompleksitas akuntansi, dan probabilitas kebangkrutan terhadap tingkat manajemen laba. Pada tabel 5 juga terlihat bahwa terdapat beberapa variabel yang mengalami kekonsistenan hasil signifikasi pada model 1a dan model 1c. Hal ini dikarenakan pengukuran variabel dependen model 1a merupakan bagian dari variabel dependen model 1c. Sedangkan, untuk model $1 \mathrm{~b}$, dapat dilihat hanya variabel KAP dan SIZE yang signifikan terhadap variabel INTRM. Hal ini disebabkan karena variabel independen lainnya yang digunakan telah berperan dalam model 1a (periode audit delay) sehingga variabel tersebut tidak signifikan secara parsial menjelaskan variasi dari variabel dependen pada model 1b. Selain itu, lama waktu penyampaian laporan keuangan setelah tanggal tanda tangan laporan auditor mungkin lebih dipengaruhi oleh keputusan manajemen dan distribusi laporan keuangan.

\section{Analisa Pengaruh Konvergensi IFRS Efektif 2011 terhadap Timeliness}

Pengujian hipotesis 1a ditujukan untuk melihat pengaruh konvergensi IFRS pada PSAK yang efektif 2011 terhadap timeliness (audit dan report delay). Hasil regresi pada tabel 5 model 1a menunjukkan bahwa variabel PSAK berpengaruh positif dan signifikan terhadap variabel ARL. Hal ini mengindikasikan bahwa penerapan PSAK yang telah konvergen dengan IFRS dan efektif pada tahun 2011 memperpanjang audit report lag sebesar 2.16 hari, dengan variabel lain dianggap konstan. Hasil ini mendukung hipotesis 1a sehingga hipotesis yang diajukan diterima. Pada tabel 5 model $1 \mathrm{~b}$ dapat dilihat bahwa variabel PSAK tidak menunjukkan pengaruh yang signifikan terhadap variabel INTRM. Hal ini mengindikasikan bahwa pada tahun 2011, penerapan PSAK yang telah konvergen dengan IFRS dan efektif 2011 tidak memperpanjang lama waktu penyampaian laporan keuangan setelah tanggal tanda tangan laporan auditor, dengan variabel lain dianggap konstan. Hal ini dikarenakan penyampaian laporan keuangan setelah tanda tangan auditor lebih ditentukan oleh keputusan manajemen. Pada tabel 4.3 Model 1c dapat dilihat bahwa variabel PSAK berpengaruh positif dan signifikan terhadap variabel TPERIOD. Hal 
ini menunjukkan bahwa pada tahun 2011, penerapan PSAK yang telah konvergen dengan IFRS dan efektif di 2011 memperpanjang waktu report delay secara total (penjumlahan periode ARL dengan INTRM) sebesar 3.13 hari, dengan variabel lain diang- gap konstan. Hasil ini mendukung hipotesis 1a yang menyatakan bahwa konvergensi IFRS dalam PSAK yang efektif tahun 2011 berpengaruh positif terhadap audit dan report delay. Dengan demikian, hipotesis 1a diterima.

Tabel 5: Hasil Regresi Model Timeliness

Model 1a:

$$
\begin{aligned}
A R L_{i t}=\alpha+ & \beta_{1} \text { PSAK }_{i t}+\beta_{2} \text { COMPLX }_{i t}+\beta_{3} \text { BANCR }_{i t}+\beta_{4} \text { GRAYAREA }_{i t}+\beta_{5} \text { SIZE }_{i t} \\
& +\beta_{6} \text { CROE }_{i t}+\beta_{7} \text { KAP }_{i t}+e_{i t}
\end{aligned}
$$

Model 1b:

$$
\begin{gathered}
\operatorname{INTRM}_{i t}=\alpha+\beta_{1} \text { PSAK }_{i t}+\beta_{2} \text { COMPLX }_{i t}+\beta_{3} \text { BANCR }_{i t}+\beta_{4} \text { GRAYAREA }_{i t}+\beta_{5} \text { SIZE }_{i t}+ \\
\beta_{6} \text { CROE }_{i t}+\beta_{7} \text { KAP }_{i t}+e_{i t}
\end{gathered}
$$

Model 1c:

$$
\begin{aligned}
\text { TPERIOD }_{i t}= & \alpha+\beta_{1} \text { PSAK }_{i t}+\beta_{2} \text { COMPLX }_{i t}+\beta_{3} \text { BANCR }_{i t}+\beta_{4} \text { GRAYAREA }_{i t}+\beta_{5} \text { SIZE }_{i t} \\
& +\beta_{6} \text { CROE }_{i t}+\beta_{7} \text { KAP }_{i t}+e_{i t}
\end{aligned}
$$

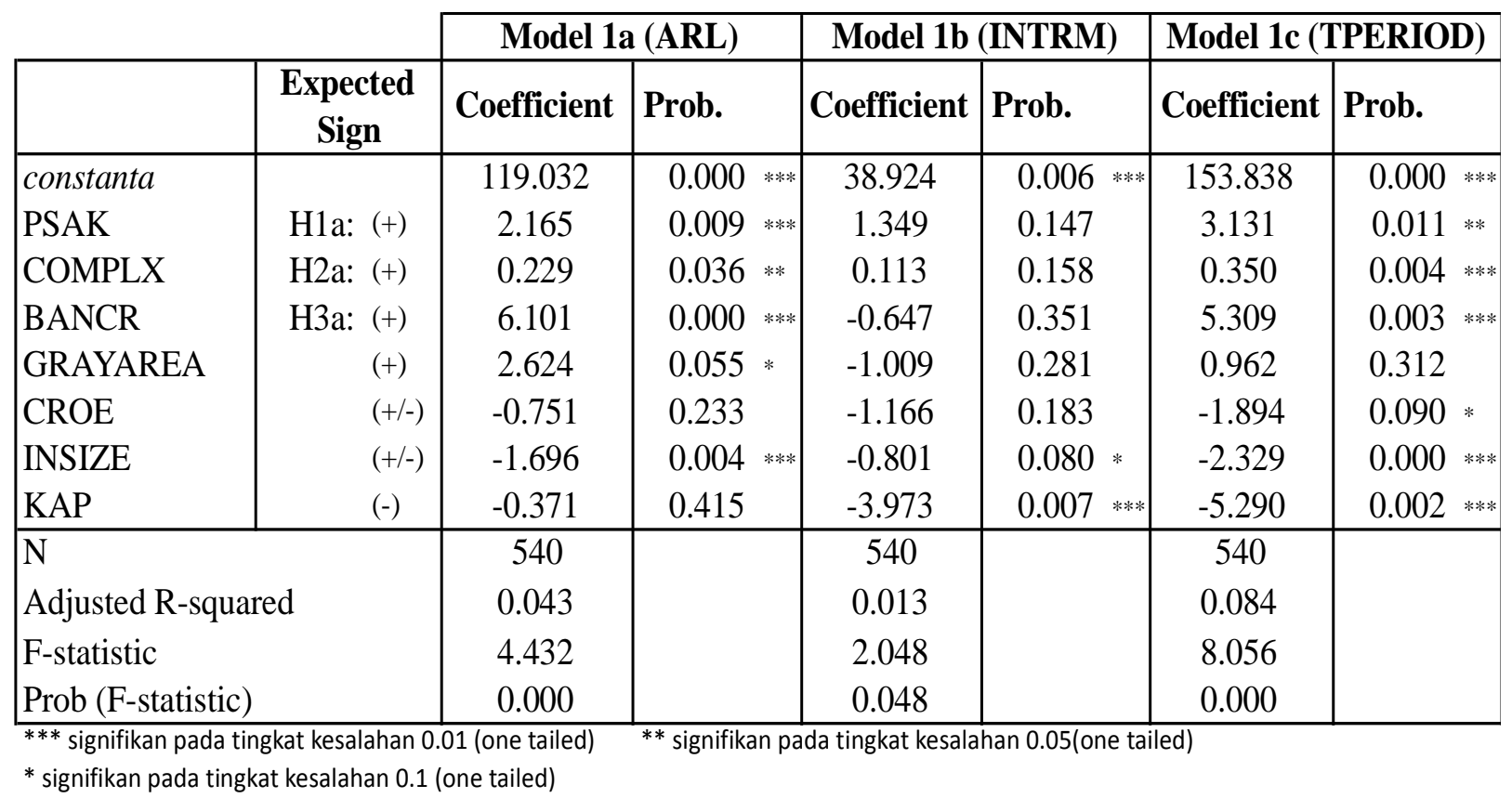

$\mathrm{ARL}=$ jumlah hari dari tanggal berakhirnya laporan keuangan hingga tanggal tanda tangan opini; INTRM = jumlah hari dari tanggal tanda tangan opini hingga tanggal publikasi di BEI; TPERIOD = jumlah hari dari tanggal berakhirnya laporan keuangan hingga tanggal publikasi; PSAK = variabel dummy tahun penerapan PSAK yang konvergen dengan IFRS dan efektif 2011 efektif 2011, 1 untuk tahun 2011 dan 0 jika bukan; COMPLX = Jumlah anak perusahaan; BANCR = variabel dummy dari sampel dengan status probabilitas bangkrut, 1 jika perusahaan memiliki nilai Altman Z Score di bawah 1.81 dan 0 jika bukan; GRAYAREA = variabel dummy perusahaan dengan status probabilitas berada di daerah rawan, 1 jika perusahaan memiliki nilai Altman Z Score antara 1.81-2.9 dan 0 jika bukan; SIZE = total aset perusahaan; $\mathrm{CROE}=$ perubahan rasio nilai laba bersih perusahaan dibagi total ekuitas tahun bersangkutan dengan tahun sebelumnya; KAP = variabel dummy yang diberi nilai 1 jika sampel di audit dari KAP Big Four dan 0 jika bukan. 


\section{Analisa Pengaruh Kompleksitas Akuntansi terhadap Timeliness}

Pengujian hipotesis 2a ditujukan untuk melihat pengaruh kompleksitas akuntansi yang diukur dengan dengan jumlah anak perusahaan terhadap timeliness (audit dan report delay). Pada tabel 5 model 1a terlihat bahwa variabel COMPLX memiliki koefisien positif dan signifikan terjadap variabel ARL. Dengan demikian, hasil penelitian ini mendukung hipotesis 2 a sehingga hipotesis 2 a diterima. Pada tabel 5 model $1 \mathrm{~b}$ variabel COMPLX tidak berpengaruh signifikan terhadap variabel INTRM. Hal ini menunjukkan kompleksitas akuntansi dari banyaknya anak perusahaan tidak memiliki pengaruh signifikan terhadap lama waktu penyampaian laporan keuangan setelah tanggal tanda tangan laporan auditor. Ketidaksignifikanan dari koefisien tersebut dapat dijelaskan karena variabel kompleksitas sudah berperan dalam menentukan audit delay dan keputusan penyampaian laporan keuangan biasanya diputuskan oleh manajemen. Hasil penelitian ini konsisten dengan penelitian yang dilakukan oleh Al-Ajmi (2008). Hasil regresi pada tabel 5 model 1c menunjukkan bahwa variabel COMPLX berpengaruh positif dan signifikan terhadap variabel TPERIOD. Dengan demikian, hasil penelitian ini mendukung hipotesis 2 a yang menyatakan bahwa jumlah anak perusahaan memperpanjang audit dan report delay sehingga hipotesis $2 \mathrm{a}$ diterima.

Jumlah anak perusahaan yang besar akan meningkatkan kompleksitas audit sehingga auditor butuh waktu yang lebih panjang untuk menjalankan proses audit, seperti memverifikasi apakah laporan keuangan konsolidasi telah mengungkapkan transaksi dengan anak perusahaan. Transaksi dengan pihak yang memiliki hubungan istimewa (anak perusahaan) dapat meningkatkan risiko audit karena auditor bisa saja tidak tanggap atas hubungan perusahaan dengan anak perusahaan yang tidak dimiliki langsung oleh perusahaan. Dengan demikian, jumlah anak perusahaan berdampak pada peningkatan audit delay. Kompleksitas bisnis juga berpengaruh postif signifikan terhadap report delay karena perusahaan dengan kompleksitas bisnis dan akuntansi yang tinggi menghadapi biaya pemrosesan informasi yang banyak sehingga memungkinkan memproduksi laporan keuangan yang kurang handal untuk memenuhi ketepatwaktuan. Hasil penelitian ini sesuai dengan penelitian sebelumnya yang dilakukan oleh Ng dan Tai (1994), Sengupta (2004) dan Al Ajmi (2008).

\section{Analisa Pengaruh Probabilitas Kebang- krutan terhadap Timeliness}

Pengujian hipotesis 3a ditujukan untuk melihat pengaruh status probabilitas kebangkrutan terhadap timeliness (audit dan report delay). Pada tabel 5 model 1a variabel BANCR berpengaruh positif dan signifikan terhadap variabel ARL. Hal ini menunjukkan bahwa perusahaan yang diprediksi berada di daerah kebangkrutan berdasarkan probabilitas kebangkrutan nilai Altman $\mathrm{Z}$ Score akan memililiki audit delay yang lebih panjang sebesar 6.10 hari. Hasil ini mendukung bahwa hipotesis 3a bahwa probabilitas kebangkrutan berhubungan positif dengan audit delay sehingga hipotesis 3a diterima. Sedangkan variabel GRAYAREA juga berpengaruh positif dan signifikan terhadap variabel ARL. Hal ini berarti yang masuk dalam daerah rawan bangkrut signifikan memperpanjang audit delay sebesar 2.6 hari.

Hasil ini konsisten dengan penelitian yang dilakukan Schwartz dan Soo (1986), bahwa perusahaan yang mengalami kesulitan keuangan dan masalah going concern akan mengalami audit delay yang lebih panjang jika dibandingkan dengan perusahaan yang tidak mengalami kesulitan keuangan. Perusahaan yang berada dalam klasifikasi bangkrut menurut nilai Altman $\mathrm{Z}$ score cenderung mengalami kesulitan keuangan sehingga auditor memerlukan waktu yang lebih banyak untuk melakukan prosedur audit serta mencari tahu rencana manajemen terhadap status going concern perusahaan. Auditor juga perlu mengevaluasi keefektifan rencana manajemen untuk mengurangi dampak kondisi dan peristiwa yang menyebabkan perusahaan sangsi mempertahankan status going concern perusahaan. 
Tabel 6: Hasil Regresi Model Manajemen Laba

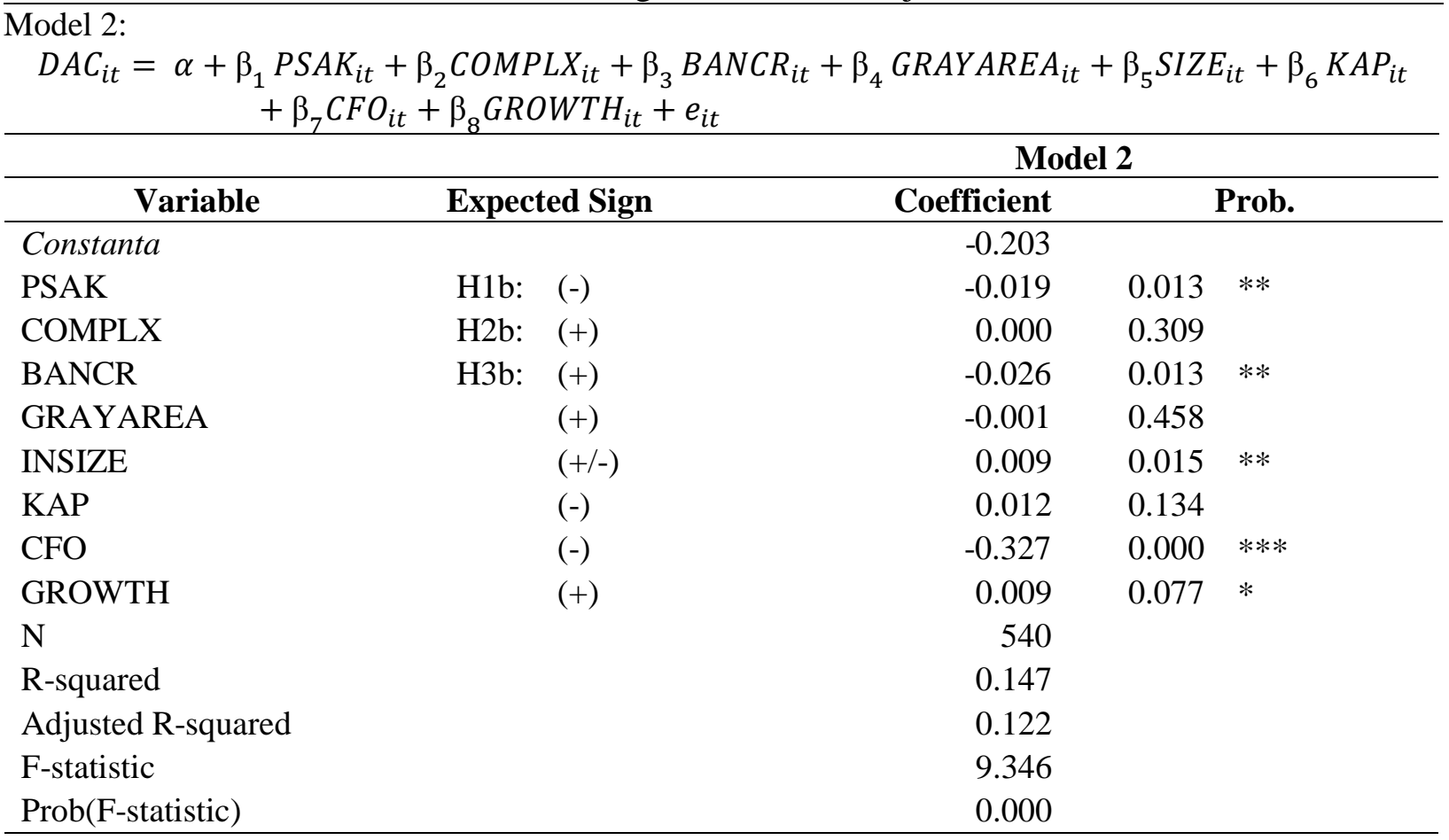

*** signifikan pada tingkat kesalahan 0.01 (one tailed) ** signifikan pada tingkat kesalahan 0.05 (one tail)

*signifikan pada tingkat kesalahan 0.1 (one tailed)

DAC = tingkat akrual diskresioner yang telah diabsolutkan, proksi dar manajemen laba;PSAK = variabel dummy tahun penerapan PSAK yang konvergen dengan IFRS dan efektif 2011, 1 untuk tahun 2011 dan 0 jika bukan; COMPLX = Jumlah anak perusahaan; BANCR = variabel dummy dari sampel dengan status probabilitas bangkrut, 1 jika perusahaan memiliki nilai Altman Z Score di bawah 1.81 dan 0 jika bukan; GRAYAREA = variabel dummy perusahaan dengan status probabilitas berada di daerah rawan, 1 jika perusahaan memiliki nilai Altman Z Score antara 1.81-2.9 dan 0 jika bukan; SIZE $=$ total aset perusahaan; KAP = variabel dummy yang diberi nilai 1 jika sampel di audit dari KAP Big Four dan 0 jika bukan; $\mathrm{CFO}=$ arus kas operasi dibagi total aset; GROWTH = pertumbuhan perusahaan yang diukur dengan persentase perubahan penjualan tahun bersangkutan dibandingkan tahun sebelumnya.

\section{Analisa Pengaruh Konvergensi IFRS Efektif 2011 terhadap Manajemen Laba}

Pengujian hipotesis $1 \mathrm{~b}$ ditujukan untuk melihat pengaruh konvergensi IFRS pada PSAK yang efektif pada tahun 2011 terhadap manajemen laba. Pada tabel 6 dapat dilihat bahwa variabel PSAK berpengaruh negatif dan signifikan terhadap variabel DAC. Hal ini berarti bahwa pada tahun 2011, konvergensi PSAK yang efektif pada tahun 2011 menurunkan tingkat manajemen laba sehingga kualitas laba meningkat. Hasil ini sesuai dengan hipotesis $1 \mathrm{~b}$ sehingga hipotesis $1 \mathrm{~b}$ diterima. Hasil ini sesuai dengan penelitian Glaum et al. (2008) dan Chen et al. (2010) yang menemu- kan bahwa periode setelah perusahaan mengadopsi IFRS, perusahaan lebih sedikit melakukan manajemen laba.

\section{Analisa Pengaruh Kompleksitas Akuntansi terhadap Manajemen Laba}

Pengujian hipotesis 2b ditujukan untuk melihat pengaruh kompleksitas akuntansi terhadap manajemen laba. Pada tabel 6 dapat dilihat bahwa variabel COMPLX tidak berpengaruh signifikan terhadap variabel DAC. Hal ini tidak sesuai dengan hipotesis $2 b$ yang menyatakan bahwa kompleksitas akuntansi berhubungan positif terhadap tingkat manajemen laba sehingga hipotesis $2 \mathrm{~b}$ ditolak. 
Penulis menduga kompleksitas akuntansi yang diukur dari jumlah anak perusahaan tidak berpengaruh signifikan terhadap manajemen laba dapat dijelaskan dengan offsetting accruals hypothesis. Jiraporn et al. (2008) berpendapat bahwa perusahaan yang terdiversifikasi akan memiliki arus kas yang tidak berkorelasi dengan sempurna sehingga akrual yang dihasilkan juga tidak berkorelasi sempurna dan cenderung saling mengimbangi dan meniadakan (cancet out) sehingga manajer akan sulit untuk mengelola laba dari kedua arah.

Selain itu, jumlah anak perusahaan mungkin memang dapat meningkatkan peluang perusahaan induk untuk mengatur transaksinya melalui anak perusahaannya. Namun, teori kontrak menjelaskan bahwa transaksi dengan pihak yang berafiliasi dapat menjadi kontrak yang efesien (Dunn dan Mayhew 2004; Kuan et al. 2010). Pandangan ini didukung oleh Gordon dan Henry (2005) dalam Kuan et al. (2010) yang berargumen bahwa transaksi dengan pihak berelasi secara rasional dapat memenuhi permintaan ekonomis perusahaan (seperti pengetahuan yang lebih luas dan expertise) sehingga keadaan tersebut menciptakan ikatan antara perusahaan induk dan anak. Konsekuensinya, keadaan tersebut mengurangi insentif untuk mengambil tindakan beresiko yang dapat merusak hubungannya dengan perusahaan seperti tindakan manajemen laba.

Penulis juga menduga karakterisitik unik pada perusahaan yang terdaftar di BEI memiliki karakteristik berupa perusahaan grup-affiliate dimana jenis perusahaan yang memiliki struktur berupa grup dapat memberikan benefit untuk anggota group berupa sumber daya tak berwujud maupun keuangan (Kuan et al. 2010), memfasilitasi pembangunan dengan menyediakan struktur organisasional yang lebih tepat untuk mengatasi kurangnya ketersediaan atas basic input dan jasa (Fisman dan Khanna 2004)

Dengan demikian, manajer tidak melihat bahwa transaksi dengan pihak berelasi seperti anak perusahaan sebagai area dimana mereka dapat memanajemen laba dengan mudah. Hasil ini tidak konsisten dengan pene- litian Thomas et al. (2004) yang menemukan transaksi dengan pihak berelasi bagi perusahan dengan jumlah anak perusahaan yang banyak akan melakukan manajemen laba lebih agresif daripada perusahaan dengan anak perusahaan yang lebih sedikit.

\section{Analisa Pengaruh Probabilitas Kebang- krutan terhadap Manajemen Laba}

Pengujian hipotesis $3 \mathrm{~b}$ ditujukan untuk melihat pengaruh probabilitas kebangkrutan terhadap manajemen laba. Pada tabel 6 dapat dilihat bahwa variabel BANCR berpengaruh negatif dan signifikan terhadap variabel DAC. Hal ini menunjukkan perusahaan yang diklasifikasikan akan bangkrut berdasarkan Altman Z-Score cenderung menurunkan tingkat manajemen labanya Hal ini mendukung hipotesis $3 \mathrm{~b}$ yang menyatakan bahwa probabilitas kebangkrutan berpengaruh terhadap manajemen laba. Akan tetapi, arah koefisien yang negatif tidak sesuai dengan ekspektasi sebelumnya. Dengan demikian hasil penelitian hipotesis $3 \mathrm{~b}$ ditolak.

Hal ini menandakan bahwa perusahaan yang mengalami financially distressed tidak terbukti melakukan manajemen laba. Hal tersebut disebabkan karena perusahaan tersebut bertindak lebih konservatif dan berpikir bahwa tindakan manajemen laba yang dilakukan oleh perusahaan tersebut akan menjadi tidak berguna dan tidak terlalu mempengaruhi hasil dan kinerja perusahaan. Selain itu, manajer pada perusahaan yang mengalami financial distressed memiliki 'ruang' yang lebih sempit dalam menggunakan akrual diskresioner karena beberapa operasional perusahaan cenderung mengalami kemandekan bahkan tidak berjalan lagi. Hasil penelitian ini sesuai dengan penelitian yang dilakukan oleh Demirkan et al. (2004) yang menemukan bahwa perusahaan yang status probabilitas bangkrut akan memiliki tingkat akrual diskresioner yang lebih kecil. Selain itu, tingkat manajemen laba yang rendah pada perusahaan yang mengalami financial distress juga mungkin disebabkan oleh kesempatan untuk melakukan manajemen laba pada perusahaan tersebut sangatlah sedikit karena adanya peng- 
awasan dari auditor, bank, investor, pemerintah yang lebih ketat. Akhirnya perusahaan tersebut tidak memiliki kecendrungan untuk melakukan manajemen laba (Bushee 1998).

\section{Analisa Hasil Pengujian Tambahan}

Untuk menguji sensitivitas dari hasil pengujian hipotesis utama, maka dilakukan pengujian tambahan dimana model timeliness dan manajemen laba akan kembali uji dengan meperhitungkan komite audit. Penambahan pengujian dengan variabel komite audit didasarkan pada penelitian Klein (2002) yang menemukan bahwa perusahaan yang membentuk komite audit yang bertugas me-review laporan keuangan perusahaan dan mengevaluasi internal kontrol perusahaan memiliki tingkat manajemen laba yang lebih rendah dan kualitas laba yang lebih tinggi.

Peneliti menilai efektivitas komite audit berdasarkan penilaian efektivitas komite audit yang dikembangkan oleh Hermawan (2009) yang meliputi jumlah pertemuan yang diadakan oleh komite audit, kehadiran anggota komite audit dalam rapat, ukuran komite audit, serta jumlah anggota komite audit yang memiliki latar belakang akuntansi.

Hasil pengujian hipotesa menunjukkan hasil yang konsisten dengan pengujian hipotesis utama untuk setiap model audit delay dan manajemen laba. Hasil pengujian tambahan ini juga menunjukkan bahwa variabel komite audit tidak terbukti mempengaruhi variabel audit delay maupun besaran akrual diskresioner manajemen secara signifikan.

Hasil serupa ditemukan dalam penelitian Fitriasary (2007) dan Al-Ajmi (2008). Al Ajmi (2008) menemukan faktor tata kelola perusahaan berpengaruh positif dan marginally significant terhadap periode interim namun tidak signifikan terhadap audit delay dan report delay. Fitriasary (2007) menemukan bahwa komite audit tidak signifikan berpengaruh terhadap manajemen laba. Hal ini dikarenakan komite audit di Indonesia masih bersifat mandatory saja dan belum kesadaran penuh untuk melaksanakan tugasnya dengan efektif dan output yang jelas.

\section{SIMPULAN}

Penelitian ini ditujukan terutama untuk memberikan bukti secara empiris mengenai pengaruh konvergensi IFRS, kompleksitas akuntansi, dan status probabilitas kebangkrutan perusahaan terhadap timeliness dan manajemen laba. Berdasarkan penelitian mengenai pengaruh konvergensi IFRS, kompleksitas akuntansi, dan status probabilitas kebangkrutan perusahaan terhadap timeliness dan manajemen laba yang telah dilakukan, diperoleh kesimpulan sebagai berikut: 1) Konvergensi IFRS dalam PSAK yang efektif di tahun 2011 memiliki pengaruh positif signifikan terhadap audit delay dan report delay. 2) Kompleksitas akuntansi yang diukur dengan jumlah anak peusahan memiliki pengaruh positif signifikan terhadap audit delay dan report delay. 3) Perusahaan dengan status probabilitas kebangkrutan memiliki pengaruh positif signifikan terhadap audit delay dan report delay. 4) Konvergensi IFRS dalam PSAK yang efektif di tahun 2011 memiliki pengaruh negatif signifikan terhadap tingkat manajemen laba. 5) Kompleksitas akuntansi tidak berpengaruh signifikan terhadap tingkat manajemen laba. 6) Perusahaan dengan status probabilitas kebangkrutan memiliki pengaruh negatif signifikan terhadap tingkat manajemen laba.

Adapun keterbatasan penelitian dan saran untuk penelitian selanjutnya adalah sebagai berikut: 1) Periode sampel yang digunakan dalam penelitian ini hanya meliputi periode sebelum dan sesudah konvergensi IFRS dalam PSAK yang efektif ditahun 2011. Sedangkan konvergensi IFRS pada PSAK di Indonesia dilakukan secara bertahap sejak tahun 2008, sehingga diharapkan untuk penelitian selanjutnya periode yang digunakan lebih panjang. Dengan demikian dapat terlihat kekonsistenan hasil penelitian hingga PSAK sepenuhnya konvergen dengan IFRS. 2) Penelitian ini hanya menggunakan perusahaan dalam industri non-keuangan sehingga diharapkan dalam penelitian selanjutnya untuk menggunakan perusahaan dalam industri keuangan. 3) Penelitian ini tidak mengelompokkan perusahaan ke dalam sektor-sektor industri. Penelitian selanjutnya diharapkan menge- 
lompokkan perusahaan untuk memberi penjelasan lebih lanjut apakah akan ada pengaruh yang berbeda yang diberikan oleh variabel-variabel independen terhadap variabel dependen untuk masing-masing sektor. 4) Penelitian ini membuktikan bahwa perusahaan yang diprediksi bangkrut tidak melakukan manajemen laba lebih besar dibandingkan dengan yang tidak sehingga kualitas laba yang dilaporkan lebih baik. Namun, penelitian ini tidak dapat menangkap perusahaan yang telah berhasil melakukan manajemen laba dan berhasil mengubah nilai Z-Score yang mebuat perusahaan bergeser klasifikasinya. Hal ini karena probabilitas kebangkrutan dihitung dengan angka angka akuntansi yang bersifat noisy dimana angka tersebut mungkin telah dimanipulasi. 5) Penelitian ini menggunakan variabel timeliness dan manajemen laba untuk mengukur kualitas laporan keuangan. Penelitian selanjutnya diharapkan dapat menggunakan ukuran kualitas laporan keuangan lainnya seperti value-relevance dan predictive ability. 6) Kompleksitas Akuntansi dalam penelitian ini diukur hanya dengan menggunakan jumlah anak perusahaan. Penelitian selanjutnya dapat menggunakan ukuran lain seperti jumlah diversifikasi segmen operasi maupun geografis. 7) Probabilitas Kebangkrutan pada penelitian ini menggunakan Altman Z-Score yang merupakan model dari luar negeri dan belum tentu tepat untuk di Indonesia. Penelitian selanjutnya dapat dikembangkan dengan menggunakan model prediksi kebangkrutan lainnya dalam menggambarkan kondisi perusahaan serta melakukan uji sensitivitas antara model tersebut. 8) Pengukuran akrual diskresioner merupakan hasil dari noisy information environment sehingga dapat mempengaruhi hasil yang diperoleh. Penelitian selanjutnya diharapkan dapat mencari model akrual diskresioner lain yang lebih valid.

\section{DAFTAR REFERENSI}

Aktas, R., and M. Kragin. 2011. Timeliness of reporting and the quality of financial information. International Research Journal of Finance and Economics 63 (1): 71-77.
At Ajmi, J. 2008. Audit and reporting delays: Evidence from an emerging market. Advances in Accounting, Incorporating Advances in International Accounting 24 (2): 217-226.

Ashton, R. H., J. J. Willingham., and R. K. Elliot. 1987. An empirical analysis of audit delay. Journal of Accounting Research Autumn, 25 (2): 275-292.

Bamber, E. M., L. S. Bamber., and M. P. Schoderbek. 1993. Audit structure and other determinants of ARL: An empirical analysis. Auditing: A Journal of Pracrice \& Theory 12 (1): 1-23.

Burgstahler, D., and I. Dichev. 1997. Earnings management to avoid earnings decreases and losses. Journal of Accounting \& Economics 24 (1): 99-126.

Bushee, B.J. 1998. Institutional investors, long-term investment, and earnings management. The Accounting Review 73 (3): 305-333.

Carslaw, C., and S. E. Kaplan. 1991. An examination of audit delay: Futher evidence from New Zealand. Accounting and Business Research 22 (85): 2132.

Charitou, A., Lambertides, N., and L. Trigeorgis. 2007. Managerial discretion in distressed firms. The British Accounting Review 39 (4): 323 346.

Chen, H., Tang, Q., Jiang, Y., and Z. Lin. 2010. The role of international financial reporting standards in accounting quality: Evidence from the European Union. Journal of International Financial Management \& Accounting 21 (3): 220-278.

DeAngelo, H., DeAngelo, L., and D. J. Skinner. 1994. Accounting choice in troubled companies. Journal of Accounting and Economics 17 (1): 113-143. 
Dechow, P. M., Sloan, R. G., and A. P. Sweeney. 1995. Detecting earnings management. The Accounting Review 70 (2): 193-225.

DeFond, M. L., and J. Jiambalvo. 1994. Debt covenant violation and manipulation of accruals. Journal of Accounting and Economics 17 (1): 145-176.

Demirkan, S., and H. D. Platt. 2009. Financial status, corporate governance quality, and the likelihood of managers using discretionary accruals. Accounting Research Journal, 22 (2): 93-117.

Dichev, I. D., and D. J. Skinner. 2002. Largesample evidence on the debt covenant hypothesis. Journal of Accounting Research 40 (4): 1091-1123.

Dunn, K. A., and B. W. Mayhew. 2004. Audit firm industry specialization and client disclosure quality. Review of Accounting Studies 9 (1): 35-58.

Dyreng, S., Hanlon, M., and E. L. Maydew. 2011. Where do firms manage earnings? Diakses pada 4 Oktober 2012, dari SSRN: http://ssrn.com/abstract=1849244.

Fanny, M., dan S. Saputra. 2005. Opini audit going concern: Kajian berdasarkan model prediksi kebangkrutan, pertumbuhan perusahaan, dan reputasi kantor akuntan publik (Studi pada emiten bursa efek Jakarta). Simposium Nasional Akuntansi VIII: 966-978.

Fisman, R., and T. Khanna. 2004. Facilitating development: The role of business group. World Development 32 (4): 609-628.

Fitriasary, D. 2007. Pengaruh aktivitas dan financial literacy komite audit terhadap manajemen laba. Tesis tidak diterbitkan, Universitas Indonesia, Depok, Indonesia.

Francis, J. R., Maydew, E. L., and H. C. Sparks. 1999. The role of Big 6 auditors in the credible reporting of accruals. Auditing: A Journal of Practice \& Theory 18 (2): 17-34.

Givoly, D., and D. Palmon. 1982. Timeliness of annual earnings announcement: Some empirical evidence. The Accounting Review 57 (July): 486-508.

Glaum, M., S. Kaiser, and J. Lindemann. 2008. Earning smoothing via provisions: IFRS vs. German GAAP. Kertas kerja. ISCTE - IUL Business School.

Habib, A., and U. B. Bhuiyan. 2011. Audit firm industry specialization and the audit report lag. Journal of International Accounting, Auditing and Taxation 20 (1): 32-44.

Hadi, S., dan A. Anggraeni. 2008. Pemilihan prediktor delisting terbaik (perbandingan antara the Zmijewski model, the Altman model, dan the Springate model). Jurnal Akuntansi \& Auditing Indonesia 12 (2): 177-186.

Haw, I, Qi, D., and W. Wu. 2000. Timeliness of annual report releases and market reaction to earnings announcements in an emerging capital market: The case of China. Journal of International Financial Management \& Accounting 11 (2): 108-131.

Healy, P. M., and J. M. Wahlen. 1999. A review of the earnings management literature and its implications for standard setting. Accounting horizons, 13 (4): 365-383.

Hermawan, A.A. 2009. Pengaruh efektifitas dewan komisaris dan komite audit, kepemilikan oleh keluarga, dan peran monitoring bank terhadap kandungan informasi laba. Disertasi tidak diterbitkan, Universitas Indonesia, Depok, Indonesia.

Jaggi, B., and J. Tsui. 1999. Determinants of ARL: Further evidence from Hong Kong. Accounting and Business Research 30 (1): 17-28.

Jiraporn, P. dan Kim, Y.S., and I. Mathur. 
2008. Does corporate diversification exacerbate or mitigate earnings management? An empirical analysis. International Review of Financial Analysis 17 (5): 1087-1109.

Jones, J. J. 1991. Earnings management during import relief investigations. Journal of Accounting Research 29 (2): 193-228.

Kaznik, R. 1999. On the association between voluntary disclosure and earnings management. Journal of Accounting Research 37 (1): 57-81.

Kieso, D. E., and J. Weygandt. 2011. Intermediate accounting: IFRS edition volume 1. John Wiley and Sons.

Kim, J. B., Chung, R., and M. Firth. 2003. Auditor conservatism, asymmetric monitoring, and earnings management. Contemporary Accounting Research 20 (2): 323-359.

Klein, A. 2002. Audit committee, board of director characteristics, and earnings management. Journal of Accounting and Economics 33 (3): 375-400.

Kuan, L., Tower, G. D., Rusmin, R., and J. M. Van der Zahn. 2010. Related party transactions and earnings management. Jurnal Akuntansi dan Auditing Indonesia 14 (2): 115-137.

Leventis, S., Weetman, P., and C. Caramanis. 2005. Determinants of audit report lag: Some evidence from the Athens Stock Exchange. International Journal of Auditing 9 (1): 45-58.

Moses, D. 1987. Income smoothing and incentives: Emperical test using accounting changes. The Accounting Review 62 (2): 358-377.

Ng, P. P. H. and B. Y. K. Tai. 1994. An empirical examination of the determinants of audit delay in Hong Kong. British Accounting Review 26 (1): 43-59.
Schipper, K. 1989. Commentary on earnings management. Accounting horizons 3 (4): 91-102.

Schwartz, K. B., and B. S. Soo. 1996. The association between auditor changes and reporting lags. Contemporary Accounting Research 13 (1): 353-370.

Scott, W. R. 2009. Financial accounting theory. New Jersey: Upper Saddle River.

Sengupta, P. 2004. Disclosure timing: Determinants of quarterly earnings release dates. Journal of Accounting and Public Policy 23 (6): 457-482.

Setyarno, E. B., Januarti, I., dan Faisal. 2006. Pengaruh kualitas audit, kondisi keuangan perusahaan, opini audit tahun sebelumnya, pertumbuhan perusahaan terhadap opini audit going concern, Sipssium Nasional Akuntansi, Padang, Indonesia: 1-25.

Siregar, S. V., dan S. Utama, S. 2005. Pengaruh struktur kepemilikan, ukuran perusahaan, dan praktek corporate governance terhadap pengelolaan laba. Jurnal Riset Akuntansi Indonesia 9 (3): 307-326.

Summers, S., and J. Sweeney. 1998. Fraudulently misstated financial statement and insider trading: An emperical analysis. The Accounting Review 73 (1): $131-146$

Sweeney, A. 1994. Debt covenant violations and managers' accounting responses. Journal of Accounting and Economics 17 (3): 281-308.

Thomas, W., Herrmann, D., and T. Inoue. 2004. Earnings management through affiliated transactions, Journal of International Accounting Research 3 (2): 1-25.

Warfield, T., Wild, J., and K. Wild. 1995. Managerial ownership, accounting choices, and informativeness of earnings. Journal of Accounting and 
Pengaruh Konvergensi, Kompleksitas ... (Asri Adika Widyawati \& Viska Anggraita)

Economics 20 (1): 61-91.

Yaacob, N. M., and A. Che-Ahmad. 2012. Audit fees after IFRS adoption: Evidence from Malaysia. Eurasian Business Review 2 (1): 31-46.

Yacoob, N. M. 2012. Adoption of IFRS and audit delay in Malaysia. International
Journal of Economics and Finance 4 (1): 167-176.

Zhou, J., and G. J. Lobo. Disclosure quality and earnings management. Diakses pada 4 Oktober 2012, dari http://ssrn.com/abstract=265550. 